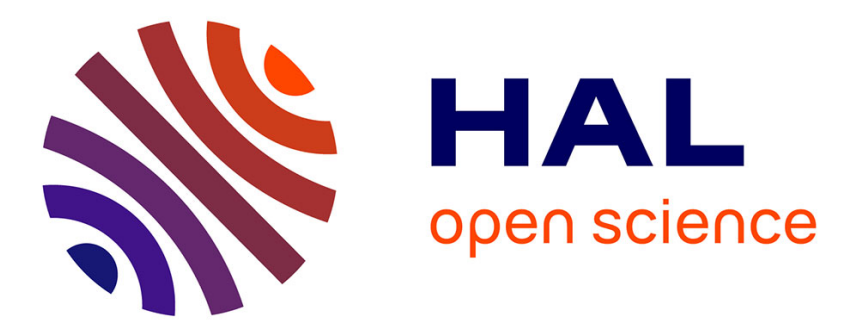

\title{
cDNA library construction for next-generation sequencing to determine the transcriptional landscape of Legionella pneumophila
}

\author{
Tobias Sahr, Carmen Buchrieser
}

\section{- To cite this version:}

Tobias Sahr, Carmen Buchrieser. cDNA library construction for next-generation sequencing to determine the transcriptional landscape of Legionella pneumophila. Carmen Buchrieser; Hubert Hilbi. Legionella: Methods and Protocols, 954, Humana Press, pp.555-566, 2013, Methods in Molecular Biology (MIMB), 978-1-62703-160-8 (Hardcover), 978-1-4939-6274-7 (Softcover), 978-1-62703-161-5 (eBook). 10.1007/978-1-62703-161-5_34 . pasteur-01334075

\section{HAL Id: pasteur-01334075}

\section{https://hal-pasteur.archives-ouvertes.fr/pasteur-01334075}

Submitted on 6 Feb 2018

HAL is a multi-disciplinary open access archive for the deposit and dissemination of scientific research documents, whether they are published or not. The documents may come from teaching and research institutions in France or abroad, or from public or private research centers.
L'archive ouverte pluridisciplinaire HAL, est destinée au dépôt et à la diffusion de documents scientifiques de niveau recherche, publiés ou non, émanant des établissements d'enseignement et de recherche français ou étrangers, des laboratoires publics ou privés.

\section{(ㄷ)(1) $(2$}

Distributed under a Creative Commons Attribution - NonCommerciall 4.0 International 
6

7

8

20

21

22

23

24

25

26

27

28

cDNA library construction for Next Generation Sequencing (NGS) to determine the transcriptional landscape of Legionella pneumophila

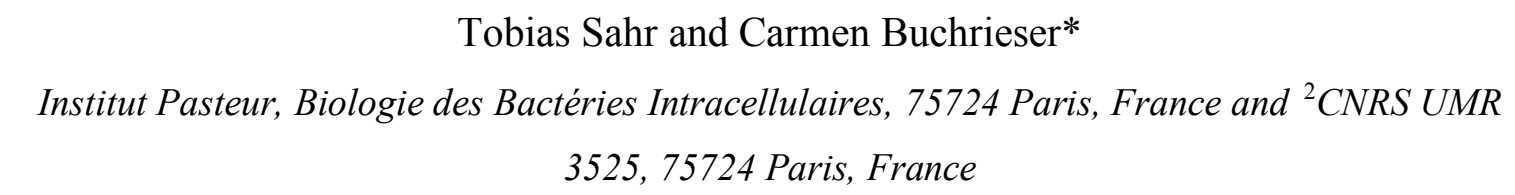

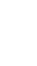

5 Running title: RNAseq of Legionella

6

18 Key words: Legionella pneumophila, next generation sequencing, transcriptional start site mapping, small ncRNA 


\section{Summary}

The adaptation of Legionella pneumophila to the different conditions it encounters in the environmental and in the host is governed by a complex regulatory system. Current knowledge of these regulatory networks and the transcriptome responses of L. pneumophila is mainly based on microarray analysis and limited to transcriptional products of annotated protein-coding genes. The application of the Next Generation Sequencing (NGS) technology allows now genome wide strand-specific sequencing and accurate determination of all expressed regions of the genome to reveal the complete transcriptional network and the dynamic interplay of specific regulators on a genome wide level. NGS based techniques promote deeper understanding of the global transcriptional organization of L. pneumophila by identifying transcription start sites (TSS), alternative TSS and operon organization, noncoding RNAs (ncRNA), antisense RNAs and 5'-/3'untranslated regions. In this chapter we describe the construction of cDNA libraries for (i) RNA deep sequencing (RNA-seq) and (ii) transcription start site (TSS) mapping using the Illumina technology.

\section{Introduction}

In recent years, the field of microbial genomics has changed considerable due to the development of new generation sequencing techniques (1). Thus, deep RNA sequencing is now revolutionizing our understanding of the complexity, plasticity and regulation of microbial transcriptomes (2). Recent studies using RNA deep sequencing indicate that the function of untranslated transcriptional regions as posttranscriptional regulator was underestimated in bacteria until now (3-6). In particular the unexpected high amount of ncRNAs found so far strongly suggests that they play a more dominant and widespread role in regulation of gene expression including a) transcription interference/termination b) translational interference c) effects on the stability of target RNA and d) interaction with RNA-binding proteins (for review see (7)). To date the L. pneumophila transcriptome was analyzed mainly using microarrays (8-12). Recently the first study using NGS techniques to analyze the intracellular transcriptome was applied to L. pneumophila allowing to discover 70 novel small RNAs (13). However, the application of NGS for an in-depth transcriptional analysis of L. pneumophila may revolutionize our understanding of adaptive and developmental processes during infection, as it will add new levels of control to our regulatory network. In the following, we present several strategies to construct strandspecific cDNA libraries for Illumina sequencing. A protocol for strand-specific RNA deep 
sequencing (RNAseq) and two different methods to enrich and define transcriptional start sites (TSS mapping).

Parallel deep sequencing of the whole transcriptome (RNAseq) reveals detailed prediction of gene expression by determination of length and abundance of transcripts including 5'and 3'-untranslated region or antisense transcription at different conditions. Anyhow, RNAseq has its limitation as it is not possible to distinguish primary transcripts from processed 5' ends, so, it cannot be used e.g. for identification of alternative transcription starts or operon organization. To achieve a more precise view on the level of primary transcripts it is necessary to construct specific TSS mapping libraries in which the 5'ends of the RNA are highly enriched in comparison to an untreated cDNA control library. We can distinguish between two different approaches to analyze the TSS region:

1) Terminator Exonuclease (TEX) method: differential cDNA library pairs treated $(+)$ or not treated (-) with TEX. Primary transcripts in bacteria like mRNA and ncRNA (but not rRNA) are known to be protected by a triphosphate cap at the 5'end. TEX digests specifically RNA having a 5'-monophosphate, but is not able to degrade RNA with a 5'-PPP protection. Therefore, TEX eliminates processed transcripts like partially degraded or sheared RNA leading to an enrichment of primary bacterial transcripts with intact 5'-triphosphate terminus (Fig 1).

2) Tobacco Acid Pyrophosphatase (TAP) method: differential cDNA library pairs treated $(+)$ or untreated $(-)$ with TAP. TAP hydrolyzes pyrophosphate of 5'-PPP RNA resulting in 5'monophosporylated end. This step is essential during the library construction as the 5' RNA adapter will ligated only to a 5'-monophosphorylated RNA but not to RNA with 5'-PPP terminus. For that reason, the untreated TAP (-) control library include all transcripts with 5'-P terminus while the TAP $(+)$ library additionally comprise the start sites of the transcript formally protected by the 5 'triphosphate cap (Fig 2).

\section{Materials}

\subsection{Strains and growth media}

1. Legionella pneumophila e.g. strains Paris, JR32 or Philadelphia-1 
2. AYE medium. For 1 liter dissolve $12 \mathrm{~g}$ yeast extract and $10 \mathrm{~g}$ ACES, adjust $\mathrm{pH}$ to 6.9 with $1 \mathrm{M} \mathrm{KOH}$. Add $10 \mathrm{~mL}$ of cysteine $40 \mathrm{~g} / \mathrm{L}$ and $10 \mathrm{~mL}$ of iron pyrophosphate 30 $\mathrm{g} / \mathrm{L}$. Fill volume to $1 \mathrm{~L}$ with distilled water and filter sterilize.

3. CYE plates. For 1 liter dissolve $10 \mathrm{~g}$ yeast extract and $10 \mathrm{~g}$ ACES, adjust $\mathrm{pH}$ to 6.9 with $1 \mathrm{M} \mathrm{KOH}$, add $15 \mathrm{~g}$ of agar, $2 \mathrm{~g}$ of activated charcoal and autoclave. Add $10 \mathrm{~mL}$ of filter sterilized cysteine $40 \mathrm{~g} / \mathrm{L}$ and $10 \mathrm{~mL}$ of filter sterilized ferric nitrate $25 \mathrm{~g} / \mathrm{L}$. Poor plates.

\subsection{RNA extraction}

1. Resuspension buffer: $1 / 2$ volume of Glucose $20 \%+1 / 2$ volume of Tris $25 \mathrm{mM}$ pH 7.6

2. EDTA $10 \mathrm{mM}$

3. EDTA $0.5 \mathrm{M}$

4. Glass beads, Sigma (200-300 microns Sigma G1277)

5. Water treated with DEPC

6. Phenol acid pH 4.5 (Interchim)

7. Total RNA extraction, TRIzol reagent (Invitrogen,

8. Chloroforme/alcohol isoamyl 24/1 (v/v)

9. Isopropanol (RT temperature)

10. Ethanol $70 \%$ (ice cold)

11. Tris- $\mathrm{HCl} 10 \mathrm{mM}$ pH 7.6 EDTA $1 \mathrm{mM}$

12. FastPrep Instrument to lyse bacteria 
13. $1.5 \mathrm{~mL}$ microcentrifuge tubes

3

14. Shaking platform at $37^{\circ} \mathrm{C}$

5

15. Disposable $50 \mathrm{~mL}$ polypropylene tubes

7

8

1. $10 \mu \mathrm{g}$ RNA

12

2. DNase I recombinant, RNase free

4. Terminator ${ }^{\mathrm{TM}} 5$ '-Phosphate-Dependent Exonuclease, TEX

6. RNase inhibitor (e.g. RNaseOUT ${ }^{\mathrm{TM}}$ Ribonuclease Inhibitor)

7. 3M Sodium Acetate, pH5.2

24

8. Ethanol p.a.; Ethanol 75\%

26

9. Glycogen $(20 \mathrm{mg} / \mathrm{ml})$

10. Tobacco acid pyrophosphatase 10U/ $\mu 1$, TAP (Epicentre, T19500)

30 
1 13. Superscript II Reverse Transcriptase Kit

2

14. RT Random primer $(100 \mu \mathrm{M})$ CAAGCAGAAGACGGCATACGANNNNNN

4

15. RT Specific primer $(100 \mu \mathrm{M})$ CAAGCAGAAGACGGCATACGA

6

7 16. RNA fragmentation kit (Ambion)

8

9 17. Alkaline Phosphatase

10

18. 3'-RNA adapter $(100 \mu \mathrm{M})$ P-UCGUAUGCCGUCUUCYGCUUGUidT

19. T4 Polynucleotide Kinase

20. $10 \mathrm{mM}$ dNTP mix

16

21. Certified Low Range Ultra Agarose (Biorad, 161-3106)

22. Agarose gel electrophoresis equipment

23. 0.5M EDTA pH8.0

22

24. Distilled water DNase/RNase free

24

25. Thermocycler

26

26. Phusion HF DNA Polymerase

27. Primer $1(25 \mu \mathrm{M})$ CAAGCAGAAGACGGCATACGA

30

28. Primer $2(25 \mu \mathrm{M})$ AATGATACGGCGACCACCGACAGGTTCAGA GTTCTACAGTCCGA

29. NucleoSpin ${ }^{\circledR}$ Gel and PCR Clean-up 
2 30. Bionalyzer 2100 (Agilent)

3

32. DNA 1000 Chips (Agilent, 5067-1504)

7

\section{Methods}

\subsection{RNA isolation}

1. From a glycerol stock maintained at $-80^{\circ} \mathrm{C}$, streak the strain on a CYE plate and incubate it at $37^{\circ} \mathrm{C}$ for $72 \mathrm{~h}$ until you obtain colonies in stationary phase.

2. Pick colonies from the plate and grow a pre-culture in $50 \mathrm{ml}$ polypropylene tubes overnight, $37^{\circ} \mathrm{C}$, shaking

3. Dilute the pre-culture. Grow cultures to a chosen OD and take a sample (10 $\mathrm{ml})$.

4. Centrifuge in a $15 \mathrm{ml}$ falcon tube, $5000 \mathrm{xg}$ for $5 \mathrm{~min}$ at $4^{\circ} \mathrm{C}$ in a pre-cooled centrifuge.

5. Withdraw the supernatant and flash freeze the pellet on dry ice + EtOH or proceed with the next step immediately.

6. Prepare a sarstedt tube, add $500 \mu 1$ phenol acid and 0.4 g glass beads.

7. Resuspend the bacterial pellet in $400 \mu \mathrm{l}$ resuspension buffer and $60 \mu \mathrm{l}$ EDTA $0.5 \mathrm{M}$.

8. Transfer suspension to the tubes containing phenol acid and glass beads.

9. Lyse the cells with the FastPrep apparatus with the following settings: Speed: 6.0; Time: $30 \mathrm{~s}$

10. Let stand for $1 \mathrm{~min}$ at $4^{\circ} \mathrm{C}$ and repeat step 4 once more with the same settings. 
1 11. Centrifuge for 5 minutes at $13000 \mathrm{rpm}$ at $4^{\circ} \mathrm{C}$. Transfer the top liquid phase to a

$2 \quad$ sterile eppendorf tube.

3

4 12. Add $1 \mathrm{ml}$ room-tempered Trizol. Mix very gently with a pipette till it is 'foamy' and $5 \quad$ let stand for 5 min on bench.

6

$7 \quad$ 13. Add $100 \mu$ chloroforme/IAA. Mix vigorously by shaking. Let stand for 1 minute on 8 bench.

9

15. Centrifuge $5 \mathrm{~min}$ at $13000 \mathrm{rpm}$ at $4^{\circ} \mathrm{C}$. Transfer the aqueous phase to a new eppendorf tube.

16. Add $200 \mu$ chloroforme/IAA. Mix vigorously and let stand for 1 minute at room

17. Centrifuge for 5 minutes, $13000 \mathrm{rpm}$ at $4^{\circ} \mathrm{C}$. Transfer the aqueous phase to a sterile

18. Add $500 \mu \mathrm{l}$ isopropanol and agitate by inversing the tube. Let stand for 30 minutes

19. Centrifuge 15 minutes, $13000 \mathrm{rpm}$ at $4^{\circ} \mathrm{C}$.

20. Rince the pellet with $1 \mathrm{ml}$ ice cold ethanol $70 \%$.

21. Centrifuge 5 minutes, $13000 \mathrm{rpm}$ at $4^{\circ} \mathrm{C}$.

22. Withdraw the supernatant and dry the pellet (SpeedVac or airdry on bench).

23. Resuspend the pellet in $50 \mu \mathrm{H}_{2} \mathrm{O}$.

24. Incubate for 15 minutes at $37^{\circ} \mathrm{C}$, measure the concentration aliquot and freeze to $80^{\circ} \mathrm{C}$ or use directly for library construction 
2 3.2. Transcription start sites (TSS) mapping library construction

1. RNA extraction using the TRIzol reagent (see also Note 1)

2. Depletion of rRNA using Microbe Express (Note 2)

3. TEX treatment: divide the RNA in two similar aliquots and incubate one with or without TEX (TEX-/+ library, for construction of TAP-/+ library see Note 3): $\mathrm{X} \mu \mathrm{l}$ depleted RNA (recovered from MicrobeExpress) $\mathrm{X} \mu \mathrm{l}$ RNase-free water 
2 14. 5'-RNA adapter ligation:

3

\section{$5.3 \mu 1$ RNA}

$1.2 \mu 15$ '-RNA adapter $(25 \mu \mathrm{M})$

Incubate mix for $10 \mathrm{~min}$ at $65^{\circ} \mathrm{C}$, put on ice for $1 \mathrm{~min}$ and add

$1 \mu 1 \mathrm{~T} 4$ RNA ligase buffer

$1 \mu 1$ ATP solution

$0.5 \mu 1$ RNase inhibitor

$1 \mu 1$ RNA ligase

And incubate for $6 \mathrm{~h}$ at $20^{\circ} \mathrm{C}$, following $4^{\circ} \mathrm{C}$ over night

15. Reverse Transcription using RT Random primer

$10 \mu 1$ RNA $+1.5 \mu 1$ random primer $(100 \mu \mathrm{M})$

Denature at $65^{\circ} \mathrm{C}$ for $10 \mathrm{~min}$, put on ice $1 \mathrm{~min}$ and add

$6 \mu 1$ first strand buffer

$1.5 \mu 1 \mathrm{DTT}(100 \mathrm{mM})$

$1.5 \mu 1 \mathrm{dNTP}$

$1 \mu 1$ RNase inhibitor

$7 \mu 1$ RNase-free $\mathrm{H} 2 \mathrm{O}$

$1.5 \mu 1$ Superscript II RT

16. Incubate $10 \mathrm{~min}$ at $25^{\circ} \mathrm{C}$, following $1 \mathrm{~h}$ at $42^{\circ} \mathrm{C}$

17. Size fractionation on a low range ultra $\%$ agarose gel (Note 6)

Cut the zones between 100-170nt and 170-250nt and purify independently with columns (e.g. Nucleospin)

Combine the samples of the two "zones", precipitate and resuspend pellet in $30 \mu 1$ distilled water

18. PCR amplification (Note 7)

$30 \mu 1$ template cDNA

$10 \mu 1$ Phusion HF buffer

$8 \mu 1 \mathrm{H}_{2} \mathrm{O}$

$0.5 \mu 1$ Primer $1(25 \mu \mathrm{M})$ 
$0.5 \mu 1$ Primer $2(25 \mu \mathrm{M})$

$0.5 \mu 1 \mathrm{dNTP}(25 \mathrm{mM})$

$0.5 \mu 1$ Phusion DNA Polymerase

$98^{\circ} \mathrm{C} \quad 1 \mathrm{~min}$

$98^{\circ} \mathrm{C} \quad 10 \mathrm{sec}$

$$
60^{\circ} \mathrm{C} \quad 30 \mathrm{sec}
$$

$72^{\circ} \mathrm{C} \quad 30 \mathrm{sec}$

15 cycles

$72^{\circ} \mathrm{C} \quad 10 \mathrm{~min}$

$$
4^{\circ} \mathrm{C}
$$

19. Purify PCR reaction with columns (e.g. Nucleospin)

20. Precipitate and resuspend in $10 \mu 1$

21. Check quality and quantity with the Bioanalyzer (DNA 1000)

22. Ready for Sequencing with Illumina

\subsection{RNAseq library construction}

1. RNA extraction (Trizol method, see also Note 1)

2. Depletion of rRNA using Microbe Express

After NaAc precipitation, resuspend the dry pellet in $10 \mu$ distilled $\mathrm{H}_{2} \mathrm{O}$

3. Fragmentation: the RNA was metal-catalyzed heat fragmented to sizes of around 100-200nt using the RNA fragmentation kit

$1.1 \mu 110 \mathrm{x}$ fragmentation reagent (buffered zinc solution $10 \mu 1$ RNA Incubation at $70^{\circ} \mathrm{C}$ for $5 \mathrm{~min}$ Terminate reaction by putting on ice and add $1.1 \mu 1$ stop solution 
After NaAc precipitation (Note 5), resuspend the dry pellet in $26 \mu 1$ RNase-free distilled $\mathrm{H}_{2} \mathrm{O}$

4. RNA dephosphorylation:

a) TAP treatment

Denature the RNA from step 3 for $10 \mathrm{~min}$ at $65^{\circ} \mathrm{C}$

After $1 \mathrm{~min}$ on ice, add $3 \mu 1 \mathrm{TAP}$ buffer and $1 \mu \mathrm{TAP}(10 \mathrm{U})$ and incubate for $1 \mathrm{~h}$ at $37^{\circ} \mathrm{C}$

b) Alkaline Phosphatase treatment

Add $14 \mu \mathrm{l}$ distilled $\mathrm{H} 2 \mathrm{O}, 5 \mu 1$ 10x Dephosphorylation buffer and $1 \mu \mathrm{l}$ Alkaline Phosphatase (10U) and incubate for $30 \mathrm{~min}$ at $37^{\circ} \mathrm{C}$

Phenol/Chloroform/IAA extraction (Note 4), NaAc precipitation; resuspend the dry pellet in $5.9 \mu \mathrm{l}$ distilled water

5. 3'-RNA adapter ligation

\section{$5.9 \mu 1$ RNA}

$0.6 \mu 13$ 'adapter $(100 \mu \mathrm{M})$

Incubate mix for $10 \mathrm{~min}$ at $65^{\circ} \mathrm{C}$, put on ice for $1 \mathrm{~min}$ and add

$1 \mu 1 \mathrm{~T} 4$ RNA ligase buffer

$1 \mu 1$ ATP solution

$0.5 \mu 1$ RNase inhibitor

$1 \mu 1$ RNA ligase

Incubate for $6 \mathrm{~h}$ at $20^{\circ} \mathrm{C}$, following $4^{\circ} \mathrm{C}$ over night, purify with

Phenol/Chloroform/IAA extraction and resuspend RNA after NaAc precipitation in $10 \mu 1$ distilled water

6. Re-phosphorylation of 5' end

$10 \mu 1$ RNA

$2 \mu 1$ PK buffer

$1 \mu 1$ ATP solution

$0.5 \mu 1$ RNase inhibitor 
$1 \mu 1$ Polynucleotide Kinase

$5.5 \mu 1 \mathrm{RNase}$ free $\mathrm{H} 2 \mathrm{O}$

7. Size fractionation on a low range ultra $2 \%$ agarose gel

Cut the zones between 100-170nt and 170-250nt and purify with columns (e.g. NucleoSpin). Precipitate with $\mathrm{NaAc}$ and resuspend in $5.3 \mu 1$ distilled $\mathrm{H}_{2} \mathrm{O}$

8. 5'-RNA adapter ligation:

\section{$5.3 \mu 1$ RNA}

$1.2 \mu 15$ '-RNAadapter $(25 \mu \mathrm{M})$

Incubate $10 \mathrm{~min}$ at $65^{\circ} \mathrm{C}$, on ice for $1 \mathrm{~min}$ and add

$1 \mu 1 \mathrm{~T} 4$ RNA ligase buffer (Epicentre)

$1 \mu 1$ ATP solution

$0.5 \mu 1$ RNase inhibitor

$1 \mu 1$ RNA ligase

And incubate for $6 \mathrm{~h}$ at $20^{\circ} \mathrm{C}$, following $4^{\circ} \mathrm{C}$ over night

9. Reverse Transcription using RT $\underline{\text { Specific primer }}$

$10 \mu 1$ RNA $+0.5 \mu 1$ RT $\underline{\text { Specific }}$ primer $(100 \mu \mathrm{M})$

Denature at $65^{\circ} \mathrm{C}$ for $10 \mathrm{~min}$, on ice $1 \mathrm{~min}$ and add

$6 \mu l$ first strand buffer

$1.5 \mu 1$ DTT $(100 \mathrm{mM})$

$1.5 \mu 1 \mathrm{dNTP}$

$1 \mu 1$ RNase inhibitor

$8 \mu 1$ RNase-free $\mathrm{H} 2 \mathrm{O}$

$1.5 \mu 1$ Superscript II RT

Incubate $1 \mathrm{~h}$ at $42^{\circ} \mathrm{C}$

10. Size fractionation on a low range ultra $2 \%$ agarose gel (Note 6)

Cut the zones between 100-170nt and 170-250nt and purify independently with columns (e.g. Nucleospin) 
Combine the samples of the two "zones", precipitate and resuspend pellet in $30 \mu 1$ distilled water

11. PCR amplification (see also Note 7)

$30 \mu 1$ template cDNA

$10 \mu 1$ Phusion HF buffer

$8 \mu 1 \mathrm{H}_{2} \mathrm{O}$

$0.5 \mu 1$ Primer $1(25 \mu \mathrm{M})$

$0.5 \mu 1$ Primer $2(25 \mu \mathrm{M})$

$0.5 \mu 1 \mathrm{dNTP}(25 \mathrm{mM})$

$0.5 \mu 1$ Phusion DNA Polymerase

13

$98^{\circ} \mathrm{C} \quad 1 \mathrm{~min}$

$60^{\circ} \mathrm{C} \quad 30 \mathrm{sec}$

$72^{\circ} \mathrm{C} \quad 30 \mathrm{sec}$

15 cycles

$$
72^{\circ} \mathrm{C} \quad 10 \mathrm{~min}
$$

$4^{\circ} \mathrm{C}$

Purify PCR reaction with columns (e.g. Nucleospin), precipitate and resuspend in $10 \mu 1$

12.Check quality and quantity with the Bioanalyzer (DNA 1000)

13.Ready for Sequencing with Illumina

\section{Notes}

1. Extracted RNA must be treated with DNase I, purity and concentration can be determined by measuring the absorbance at $260 \mathrm{~nm}$ an $280 \mathrm{~nm}$. Nevertheless, to 
guarantee best quality a Bioanalyzer analysis should be performed with total and rRNAdepleted RNA.

2. Microbe Express is performed according to the manufacture's instruction with $2 \times 10 \mu \mathrm{g}$ of total RNA for each condition as starting material.

3. Alternatively to the comparison of libraries treated with and without TEX, a TAP-/+ library can be constructed. For this purpose no TEX treatment is necessary! Instead, divide the depleted RNA after step 2 (MicrobeExpress treatment) in two similar aliquots and incubate one fraction with, the other without TAP as described in step 7-10 and continue with step 11.

4. Phenol/Chloroform/IAA extraction: Add $50 \%$ of Phenol to the sample and mix vigorously by vortexing. Add the same amount of Chloroform/Isoamyl alcohol and mix well. Centrifuge at maximal speed for $5 \mathrm{~min}$, transfer the supernatant to a new tube and add 1 vol of Chloroform/Isoamyl alcohol, mix vigorously, centrifuge and transfer supernatant into a new tube

5. NaAc precipitation: Add $10 \% 3 \mathrm{M}$ sodium acetate (pH5.2), $2 \%$ glycogen and $2.5 \mathrm{vol}$ of ethanol p.a. to the sample and store it $\min 2 \mathrm{~h}$ (better over night) at $-20^{\circ} \mathrm{C}$. Centrifuge at $4^{\circ} \mathrm{C}$ for $15 \mathrm{~min}$ at max speed and discard supernatant. Wash RNA pellet with $500 \mu \mathrm{l}$ icecold $75 \%$ ethanol centrifuge again for $5 \mathrm{~min}$, discard supernatant and let the pellet dry for 10min at RT. Resuspend the dry pellet RNase-free distilled $\mathrm{H}_{2} \mathrm{O}$

6. Final library with a median insert size of around $200 \mathrm{bp}$ is ideal for Illumina NGS. Anyhow, if you choose longer fragments you need to reduce your loading concentration otherwise the clusters begin to overlap due to the length. Also a too wide range of fragment size will have a negative effect on the quality and distribution of clustering.

7. Number of cycles during PCR amplification can differ between experiments depending on the amount of cDNA obtained in the previous step. Typically are 12 to maximal 17 cycles. More cycles are not recommended as additional PCR steps may introduce a significant amplification bias in cDNA representation. DNA amounts due to Bioanalyzer DNA1000 analysis are typically in a range of 10-50 nM. If much less material is obtained, adapt number of cycles in the PCR or increase the amount of starting material. For the hybridization on the Cluster Station concentrations of 1-10 pM are recommended. 
Acknowledgements

This work received support from the Institut Pasteur, the Centre national de la recherché scientifique (CNRS) and the Institut Carnot-Pasteur MI and from the ANR-10-PATH-004 project, in the frame of ERA-Net PathoGenoMics

\section{References}

1. Metzker, M. L. (2010) Sequencing technologies - the next generation, Nat Rev Genet, 1.

2. Sorek, R., and Cossart, P. (2010) Prokaryotic transcriptomics: a new view on regulation, physiology and pathogenicity, Nat Rev Genet 11, 9-16.

3. Dornenburg, J. E., Devita, A. M., Palumbo, M. J., and Wade, J. T. (2010) Widespread antisense transcription in Escherichia coli, MBio 1, e00024-00010.

4. Sharma, C. M., Hoffmann, S., Darfeuille, F., Reignier, J., Findeiss, S., Sittka, A., Chabas, S., Reiche, K., Hackermüller, J., Reinhardt, R., Stadler, P. F., and Vogel, J. (2010) The primary transcriptome of the major human pathogen Helicobacter pylori., Nature 464, 250-255.

5. Thomason, M. K., and Storz, G. (2010) Bacterial antisense RNAs: how many are there, and what are they doing?, Annu Rev Genet 44, 167-168.

6. Vivancos, A. P., Güell, M., Dohm, J. C., Serrano, L., and Himmelbauer, H. (2010) Strand-specific deep sequencing of the transcriptome., Genome Res 20, 989-999.

7. Storz, G., Vogel, J., and Wassarman, K. M. (2011) Regulation by small RNAs in bacteria: expanding frontiers., Mol Cell. 43, 880-891.

8. Bruggemann, H., Hagman, A., Jules, M., Sismeiro, O., Dillies, M. A., Gouyette, C., Kunst, F., Steinert, M., Heuner, K., Coppee, J. Y., and Buchrieser, C. (2006) Virulence strategies for infecting phagocytes deduced from the in vivo transcriptional program of Legionella pneumophila, Cell Microbiol 8, 1228-1240.

9. Dalebroux, Z. D., Yagi, B. F., Sahr, T., Buchrieser, C., and Swanson, M. S. (2010) Distinct roles of ppGpp and DksA in Legionella pneumophila differentiation, Mol Microbiol 76, 200-219.

10. Faucher, S. P., Mueller, C. A., and Shuman, H. A. (2011) Legionella pneumophila Transcriptome during Intracellular Multiplication in Human Macrophages, Front Microbiol 2, 60.

11. Sahr, T., Bruggemann, H., Jules, M., Lomma, M., Albert-Weissenberger, C., Cazalet, C., and Buchrieser, C. (2009) Two small ncRNAs jointly govern virulence and transmission in Legionella pneumophila, Mol Microbiol 72, 741-762.

12. Hovel-Miner, G., Pampou, S., Faucher, S. P., Clarke, M., Morozova, I., Morozov, P., Russo, J. J., Shuman, H. A., and Kalachikov, S. (2009) SigmaS controls multiple pathways associated with intracellular multiplication of Legionella pneumophila, J Bacteriol 191, 2461-2473. 
1 13. Weissenmayer, B. A., Prendergast, J. G., Lohan, A. J., and Loftus, B. J. (2011) 2 Sequencing illustrates the transcriptional response of Legionella pneumophila during infection and identifies seventy novel small non-coding RNAs, PLoS One 6, e17570. 
1 Fig 1 Example for TEX- (black) and TEX + (green) library comparison: Artemis software

2 image of the lpp0001-0003 region. Peaks are representing the relative coverage of strand-

3 specific reads obtained from sequencing cDNA libraries with Illumina HiSeq and mapped

4 to the L. pneumophila Paris genome.

5

6 Fig 2 Comparison of TAP- (black) and TAP+ (green) library: Artemis software image of 7 lpp0001-0003 region. Peaks are representing the relative coverage of strand-specific reads 8 obtained from sequencing cDNA libraries with Illumina HiSeq and mapped to the $L$.

9 pneumophila Paris genome. 
Figure 1.

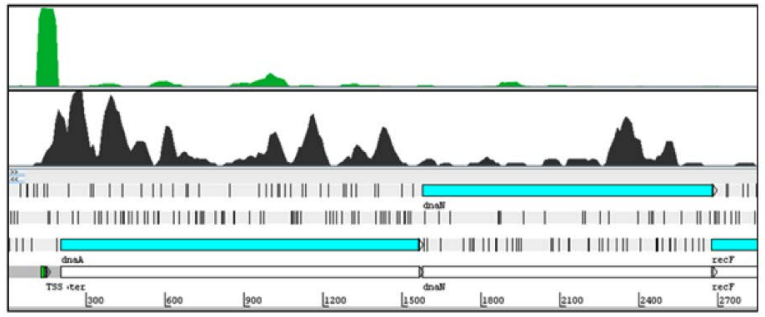


Figure 2.

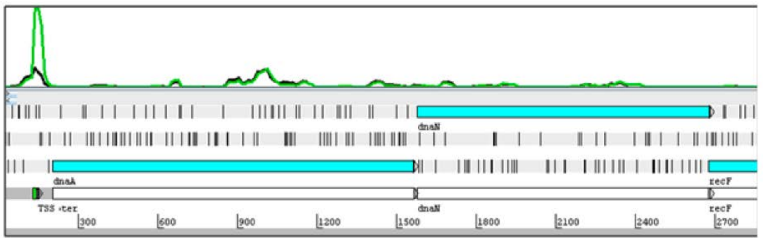

